\title{
The Legislative Role of Universal Health Coverage Achievement in Kolaka Regency
}

\author{
Rahmat Anzari ${ }^{1}$, Sukri Palutturi ${ }^{1 *}$, Aminuddin Syam² \\ ${ }^{1}$ Department of Health Administration and Policy, Public Health of Faculty, Hasanuddin University, Makassar, Indonesia; \\ ${ }^{2}$ Department of Nutrition, Public Health of Faculty, Hasanuddin University, Makassar, Indonesia
}

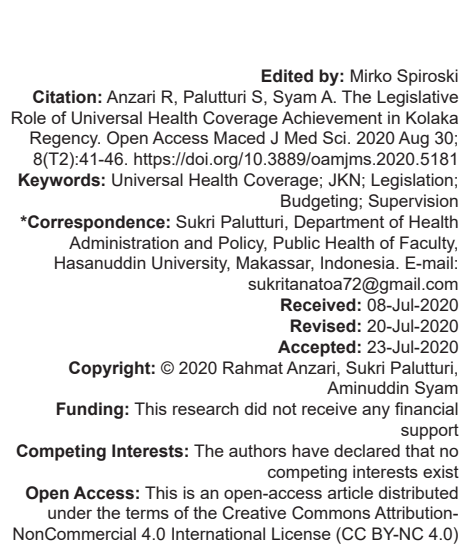

\section{Introduction}

The percentage of population guaranteed, services guaranteed and a large proportion of the direct costs still borne by the population are three dimensions formulated by the $\mathrm{WHO}$ in achieving universal coverage. Potential protective financial risk and access to care that is needed is two main objectives Universal Health Coverage (UHC). UHC also includes objectives related to equitable access, quality services, and broader social protection [1], [2].

The achievement of the UHC was supported by various factors including the BPJS, the Regional Government and the DPRD itself. Legislative role against UHC form of check and balances means the balance as well as the lack of oversight of the authority and will be given. The mechanism of checks and balances can improve the relationship between executive and legislative in realizing good governance [3].

Based on research Hoang et al. [4] in Vietnam, various levels of support from stakeholders affect the formulation and implementation of health insurance. With government financial subsidies, the involvement of various stakeholders, political commitment, and flexible working mechanisms among the stakeholders, proves that the issue of health insurance is not only a technical aspect of the health system but also a socioeconomic and broader governance problem.

Act of the National Social Security in 2004 to consider the entire population coverage through the National Health Insurance (JKN), a mandatory program that evolved from the existing insurance program [5]. Based on national data, currently JKNKIS participants in Indonesia have increased from 2014 to 2019 with the number of participants as of July 1,2019 , totaling $222,463,022$ million or around $86 \%$ of the population. While in Kolaka Regency is inversely proportional to the target that has been set even decreased, namely, the number of JKN as of December 31, 2018, totaling 217,786 inhabitants with coverage of $83.8 \%$ and as of June 30,2019 , totaling 233,159 people experienced a decrease with coverage of $83.2 \%$, from the results of these data 
show that Kolaka Regency has not yet reached the UHC dated January 1, 2019, and this is not in line with the President's instructions No. 8 of 2017 concerning the optimization of the implementation of the national health insurance program. This shows the seriousness of the regional government and especially the DPRD in achieving the UHC in Kolaka Regency.

From the results of the background of the above problems, the aims of this study are to determine the role of the legislative in particular functions of legislation, budgeting, and monitoring to the achievement of UHC yet achieved UHC in Kolaka Regency.

\section{Materials and Methods}

The study was conducted in Kolaka Regency on November 25 to December 6, 2019. This research was conducted using qualitative methods that have the aim to describe and understand the factors related to the role of the People's Representative Council on the achievement of the Universal Health Coverage (UHC) by looking at the making of three functions of the DPRD, namely, Legislation, Budgeting, and Supervision in Kolaka Regency.

Accidental sampling is a technique of determining samples based on chance that consumers who incidentally/incidentally meet with researchers can be used as samples, if it is seen that people who happen to be met are suitable as data sources. Informants in this study as many as four persons, namely, three Commission III of the DPRD Kolaka period from 2014 to 2019 and head of the healthcare in Kolaka Regency, with criteria have served a minimum of 6 months, healthy body and can communicate fluently and willing to become an informant by signing informed consent.

Data collection is collected by in-depth interviews, observations, and document review. The legislation is done by the method of document review and observation, while budgeting and supervision are carried out by the method of in-depth interviews and document review.

Data collection is collected by in-depth interviews, observations, and document review. Data analysis in qualitative research was conducted before entering the field, during the field, and after its completion in the field. Data analysis was performed using the version of Miles and Huberman that the activities in qualitative data analysis were carried out interactively and continued continuously until it was completed so that the data were saturated. Activities include data reduction, data display, and verification.

\section{Results}

Table 1 shows the names of the members of Commission III in the Field of Development and Welfare of the DPRD of Kolaka Regency as many as 11 people, of which the Gerindra was as much as 1 chair of the commission, PKS as much as 2 seats with the AKD as the deputy chairman and member, the Golkar as much as 1 seat as a secretary and the PAN, HANURA, PKB, PDIP, PKS, and PBB, respectively, as members of Commission III in the Development of the DPRD Kolaka Regency Period of 2014-2019.

Table 1: Data on board completeness tools (AKD) Commission III development and welfare members of the Kolaka Regency DPRD for the 2014-2019 period

\begin{tabular}{lll}
\hline Name & AKD structure & Fraction \\
\hline Ir. Syaifullah Halik & Chairman & Gerindra \\
Ahmar S.Sos & Vice-Chairman & PKS \\
H. Mustafa SE & Secretary & Golkar \\
Muh. Ajib Madjib, SE & Member & PAN \\
Hasbi Mustafa, SH & Member & Hanura \\
Drs. Handra, SH & Member & PKB \\
Hj. Jariah & Member & PPP \\
Edi Hariyono. Sp & Member & PDIP \\
Syarifuddin Baso Rantegau & Member & PDIP \\
Rusman, SH & Member & PKS \\
Muh. Gassing, SS & Member & PBB \\
\hline
\end{tabular}

Characteristics of the informants in this study are presented in Table 2, where all informants are in the age range ranging from 46 to 52 years with educational background S1 to S2.

Table 2: Characteristics of informants in-depth interview about the role of the legislature towards the achievement of UHC in the Kolaka Regency, 2019

\begin{tabular}{llll}
\hline Initial & Age (years) & Education & Position \\
\hline SH & 46 & S1 & $\begin{array}{l}\text { Chairman of Commission III of the Gerindra } \\
\text { HM }\end{array}$ \\
& 52 & S1 & $\begin{array}{l}\text { Faction DPRD } \\
\text { Member of Commission III DPRD Hanura }\end{array}$ \\
AM & 47 & S1 & Faction \\
AR & 50 & S2 & Member of Commission III DPRD PAN faction \\
\hline
\end{tabular}

\section{Legislation}

Based on the results of in-depth interviews about the role of the DPRD in the legislative function, it can be seen that the DPRD does not yet have regional regulations that support the achievement of $\mathrm{UHC}$ in Kolaka Regency because DPRD is still doing academic studies related to UHC. The following is the statement of the informant:

"... Surely the JKN this is the program nationwide that do government central of course we are in the area will do things like that, until the moment it does not exist regulatory regions are related or support in achieving UHC in Kolaka Regency. We at the DPRD will conduct academic studies related to the achievement of UHC in Kolaka Regency tp fulfill the healthy rights of the Kolaka Regency as a whole." (SH, 46, Chair of Commission III DPRD Gerindra Faction). 
The statement was then supported by informants from other DPRD members who said that there was no regional regulation regarding $\mathrm{JKN}$ :

"... Indeed, it is necessary to have local regulations in support of the JKN national program, specifically in the Kolaka Regency there are no local regulations relating to JKN, we DPRD will certainly work to give birth to policies or regulations which then have a wide impact on the community specifically about This JKN." (HM, 52, Member of Commission III DPRD Hanura Faction).

Then, an additional statement from the informant said that this time in Kolaka Regency, there is only an agreement in the form of an MoU between the Health Office and the Regency Health BPJS Kolaka. The following is the statement of the informant:

“... The relationship between the regional government and the DPRD Kolaka is very synergized in running the wheels of government, but until now local regulations related to supporting the achievement of universal health coverage have not yet existed in the Kolaka, only in the form of an MoU with the Regency Health Office Kolaka with BPJS Health Regency in Kolaka." (AR, 50, Head of Health Services, Kolaka Health Office).

Based on the results of interviews with informants and observations made, it can be seen that there are no regional regulations issued by the Kolaka Regency government that support UHC achievement because they are still conducting academic studies related to $\mathrm{JKN}$ and there is only an agreement in the form of an MoU between the Regency Health Office Kolaka and Kolaka BPJS Regency Health so that the legislative role in the legislative function on the achievement of UHC in Kolaka Regency has not been implemented properly because there are no regional regulations governing $\mathrm{JKN}$ in terms of achieving $\mathrm{UHC}$.

\section{Budgeting}

Information wants to know from budgeting is about the legislative role in support of the process of budgeting government area, which is associated with $\mathrm{JKN}$ and the amount of budget that issued government area of health, especially financing of participants JKN. The following is the statement of the informant regarding his role in supporting the budgeting process:

"... Regarding our budgeting in the DPRD, of course, prioritizing the budget in the field of Health, of course, we fully support that regarding the health budget, because it is also in the management of health budgets that relevant parties are able to target the community according to the programs that will be carried out later." (SH, 46, Chair of Commission III DPRD of the Gerindra Faction).
Based on this statement, the chairman of the Commission III of the District Parliament Kolaka supports and prioritizes the budget for the health sector and hopes that the budget can be targeted to the people who need it. The informant further said that while serving in Commission III, the DPRD synergized well with the local government regarding health budgeting because it involved the wider community. The following is the statement of the informant:

“... When I was a member of Commission III for the 2014-2019 period, we at the DPRD worked well with local governments in the health sector, of course, in our position of health support was because it was about the wider community." (HM, 52, Member of Commission III DPRD Hanura Faction).

Then, the informant further said his hopes to increase the amount of the health budget in the 2019 2024 period.

“... Even our Commission III Member of Kolaka $D P R D$ yesterday responded very well related to the health budget. In fact, I hope that the health budget in the 2019-2024 period can be added again." (AM, 47, Member of Commission III DPRD PAN Faction).

Regarding the number of APBDs issued by the local government for health, especially for JKN participants, the three DPRD informants were not sure of the total budget for JKN participants. The following statement:

"... As for the exact number, I also forgot a bit, but that is according to the discussion at the plenary session yesterday, then just check it directly at the health office." (SH, 46, Chair of Commission III DPRD Gerindra Faction).

"... If the exact numbers are listed, then check directly the Health Office." (HM, 52, Member of Commission III DPRD Hanura Faction).

“... I forgot the exact number, immediately checked or asked for the real number at the health office." (AM, 47, Member of Commission III DPRD Faction PAN).

For the amount of JKN budget, here is a direct statement from the informant at the Health Office:

“... The JKN budget from 2014 to 2019 continues to increase, of course, this is a form of synergy between the regional government and the DPRD in supporting the JKN program, later I will provide regional expenditure budget related to national health insurance consisting of the regional premium budget, JKN, and management from 2014-2019, for 2019 the number of APBDs for JKN is approximately 19 billion." (AR, 50, Head of Health Services, Kolaka Health Office).

Based on the results of interviews on budgeting, Commission III DPRD of Kolaka Regency gave full support regarding budgeting in the health 
sector because health concerns the wider community, evidenced by the continued increase in the number of APBDs issued for JKN from 2014 to 2019 which reached $19 \mathrm{M}$ in 2019.

\section{Supervision}

Information to be known from the supervision is about the role of DPRD in overseeing the budget for JKN. The following is the statement of the informant:

“... In overseeing the budget in supporting $J K N$, this is one of our functions in the DPRD, of course, we convey and remind that in implementing health programs it must be right on target for the people who really need it, also related to JKN-KIS recipients or the community poor we are also in the DPRD somewhat confused about the data we want to refer to where? Is it in BPS or the Social Service? Because each of the different agencies issued data so that we are also confused where to refer, we hope that the local government in managing the data of the poor is just one door so that we refer there only so that the implementation is right on target. For budget oversight, it is carried out normatively 3 times with stages 1, quarter 2 and quarter 3, but in conducting our supervision in the Kolaka $D P R D$, we often do well at the health center to hospital-level by looking at the comparison between planning and realization in the field set by the government. central, provincial and district governments as monitoring material by commission III, while the Inspectorate, BPK (Financial Supervisory Agency), and APIP (Government Internal Supervisory Apparatus) also conduct their own supervision and sometimes also the friends of the BPK submit suggestions if there are problems about JKN while examples of problems that often occur in the field are long queuing problems when health services so that we in the DPRD hold a Hearing Meeting (RDP) with the Health Service or related agencies in completing health services especially about this JKN problem." (SH, 46, Chair Commission III DPRD Gerindra Faction).

Based on interviews with the Chairperson of Commission III of the Gerindra Faction DPRD, the informant stated that budget oversight in supporting JKN had been carried out, but there was no clear data reference yet on the number of poor people in Kolaka because there are differences in the amount of data from BPS and the social service. The informant hopes that in managing the data of the poor, the population will be integrated so that the implementation of the JKN program primarily to finance PBI participants can run effectively and efficiently. Budget monitoring is carried out 3 times a year/per quarter by the DPRD in collaboration with the inspectorate, BPK, and APIP by comparing planning with reality on the ground.

The statement was supported by a statement from an informant from the Health Office who said that differences in data from the Social Service and BPS were one of the causes of the decrease in the number of membership coverage. The following is the statement of the informant:

“... Correct membership data released by the Health Service as of December 31, 2018, were 217,786 people with coverage of $83.8 \%$ and as of June 30, 2019, as many as 233,159 people experienced a decrease with coverage of $83.2 \%$ of this membership having decreased by several these factors include the existence of people having a double card, people who have moved areas and people who have died." (AR, 50, Head of Health Services, Kolaka Health Office). The informant went onto say that the DPRD Kolaka as a legislative body, has carried out its function in overseeing budget management and was included in the priority scale of discussion in the Kolaka Regency Parliament. The following is the statement of the informant:

“... I am a member of the Regional Parliament of Kolaka 2014-2019, and we with the regional government are very well partnered in realizing the welfare of the Kolaka Regency. Regarding the budget management oversight for UHC, especially JKN participant budget, we input the priority scale of discussion at the Regional Parliament yesterday. We strongly support that. And thank God the management went well according to the determined SOP." (HM, 52, Member of Commission III DPRD Hanura Faction).

The next statement regarding supervision, the informant said that the Kolaka Regency Parliament has budgeted according to the submission from the local government, especially in the health sector, and plans to add a budget for the health sector and formulate regional regulations through academic studies in support of the JKN program in the Regency. Kolaka. The following is the statement of the informant:

“... Regarding local regulations, God willing, we will conduct academic studies in formulating or making regional regulations in support of JKN in the Kolaka Regency. Later and regarding the budgeting in the health sector, especially JKN we have budgeted enough in accordance with the submission of the local government, and even we plan to add more health budgeting for the health rights of the community in the Kolaka regency." (AM, 47, Member of Commission III DPRD PAN Faction).

Based on the results of interviews regarding supervision, it can be seen that the District Parliament 
Kolaka has conducted oversight of the budget in the field of health, especially in the JKN program. However, for budgeting $\mathrm{PBI}$, participants are still experiencing problems due to differences in poor community data released by BPS and the District Social Service. Kolaka. This has become one of the causes of the decline in JKN membership coverage, namely, the existence of a double card community, people who have moved areas, and people who have died. Parliamentary budget oversight Kab. Kolaka is carried out 3 times a year/per quarter by the DPRD in collaboration with the inspectorate, BPK, and APIP by comparing planning with reality on the ground.

\section{Discussion}

This research was conducted to determine the role of the legislature, namely, legislation, budgeting, and supervision of the achievement of UHC in Kolaka Regency. Researchers discuss the results of research by analyzing these data and comparing with theories and the results of previous studies; this is to find out more research results obtained from research informant statements and after data reduction and data presentation. The discussion of each variable is stated as follows:

\section{Legislation}

Based on the results of the study, it can be seen that there are no local regulations issued by the Kolaka district government who supports the achievement of UHC because DPRD Kolaka will only conduct an academic study related to JKN and there is only an agreement in the form of an MoU between the District Health Office of Kolaka and BPJS District Health of Kolaka.

The function of legislation to form local regulations is the main function of the Regency/DPRD as a regional legislative body. The function of making local regulations is the main and original function of the DPRD as a legislative body. Through this function, Regency/City DPRDs can show their color and character and quality, both materially and functionally. This legislative function is attached to the DPRD as the DPRD is a representative institution of the people [6].

This research is then not in line with research conducted by Rismawan [7] in Palu City, which states that the provisions of the policies are carried out in general that the process of implementing the health insurance financing policy of the City of Palu in the JKN era was successfully implemented. The regional health insurance financing policy is a top-down policy from the central government to regional governments that consciously and with high commitment can be realized by the Palu City Government, both in the form of providing contribution assistance for JKN participants registered by the city government (PBI APBD) as well as several service activity programs health that has been implemented.

\section{Budgeting}

Based on the results of the study, Commission III of the District Parliament, Kolaka, has given full support regarding budgeting in the health sector because he is aware that health concerns the wider community. The amount of the budget for the JKN program from 2014, which was as much as Rp10,943,598,400, continued to increase until 2018 to Rp20,214,078,501 and experienced a slight decrease in 2019 to Rp19,837,977,100.

Increasing the amount of the budget each year shows that the district government Kolaka continues to improve and support the achievement of $\mathrm{UHC}$, especially in increasing the amount of the budget. This shows that the DPRD and local governments are actively and jointly involved in increasing the JKN program budget.

The health budget is part of the national budget allocated to the health sector, including all ministries and institutions related to health activities. The health budget allocates national funds to the sector, states the country's key financial goals, and represents a health policy commitment and strategy implementation [8].

In addition to providing the budget, the next thing to note is that the utilization of the budget is in accordance with its purpose or not. Supriantoro [9] in his research stated that for budget readiness, it involved very large state and regional funding, but the effectiveness of its use was highly considered, especially in terms of financing, so that in the end the services received by the community would be even greater and targeted.

This research is also in line with research conducted by Timumun [10], which states that the management of the National Health Insurance program in terms of the provision of funds is more effective, but in terms of utilization of the budget has not been effective.

This shows that the regional government, especially the DPRD must always oversee the budget that has been issued, not only limited to providing funds so that the budget will have an impact on improving the JKN program and its benefits are felt by the wider community.

\section{Supervision}

Based on the results of the study, it is known that the District Parliament Kolaka has conducted oversight of the budget in the field of health, especially in the JKN program. However, it has not yet implemented supervision in the area of regional regulations because there are no regional regulations regarding the JKN program. Parliamentary budget oversight Kolaka 
is done 3 times a year/per quarter by the DPRD in collaboration with the inspectorate, BPK, and APIP by comparing planning with reality on the ground.

This research is in line with research conducted by Sahri [11] in Bangkalan, which stated that the implementation of the oversight function of the District Parliament. Bangkalan on the implementation of the Jamkesda program in Kab. Bangkalan is not yet optimal due to the absence of regional regulations that specifically regulate Jamkesda.

The absence of regional regulations that specifically regulate JKN is an indication of the weak oversight of the District Parliament. Kolaka on the implementation of the supervisory function related to JKN. How does DPRD Kolaka can conduct supervision well, if there is no local regulation that specifically regulates the implementation of JKN in Kolaka. The fact that there are no regional regulations that specifically regulate JKN makes the DPRD Kolaka does not have a firm legal umbrella, especially in the level of regional regulations as a reference to carry out the supervisory function, even though local regulations related to JKN are absolutely needed, in addition to being a legal basis it also becomes a reference for the DPRD Kolaka to be free to supervise if there are policies that conflict with these regional regulations.

Constraints found by the District Parliament, Kolaka and District Health Office. Kolaka, namely, the differences in data on the poor are issued by BPS and the Kolaka District Social Service. This has become one of the causes of the decline in JKN membership coverage, namely, the existence of a double card community, people who have moved areas, and people who have died [12].

\section{Recommendation}

It is recommended to immediately formulate and issue regional regulations that support the implementation of the JKN program as a manifestation of the achievement of UHC in Kolaka and involve academic experts in UHC/JKN in formulating the regional regulation. It is hoped that further research can explore further the factors that influence community interest in becoming JKN-KIS participants, as well as $\mathrm{UHC}$ achievements from the BPJS Health aspect.

\section{Conclusion}

It is expected to immediately formulate and issue regional regulations that support the implementation of the JKN program as a manifestation of the achievement of UHC in Kolaka and involve academic experts in UHC/ $\mathrm{JKN}$ in formulating the regional regulation.

\section{References}

1. Mulupi S, Kirigia D, Chuma J. Community perceptions of health insurance and their preferred design features: implications for the design of universal health coverage reforms in Kenya. BMC Health Serv Res. 2013;13(474):1-12. https://doi. org/10.1186/1472-6963-13-474

PMid:24219335

2. Misnaniarti M, Ayuningtyas D. Achieving universal coverage lessons from the experience of other countries for national health insurance implementation in Indonesia. MPRA Paper. 2015;3(5):40-52.

3. Agapa P. Pelaksanaan fungsi legislasi DPRD dalam membuat peraturan daerah (perda) di kabupaten nabire provinsi papua tahun 2009-2014. J Renaiss. 2017;2(2):242-53. https://doi. org/10.33087/wjh.v2i1.24

4. Hoang CK, Hill P, Nguyen HT. Universal health insurance coverage in Vietnam: A stakeholder analysis from policy proposal (1989) to implementation. J Public Health Manag Pract. 2018;24(1):52-9. https://doi.org/10.1097/ phh.0000000000000729

PMid:29369257

5. Marzoeki P, Tandon A, Bi X, Pambudi ES. Universal Health Coverage for Inclusive and Sustainable Development, Country Summary Report for Indonesia. Japan: World Bank Group; 2014.

6. Suranto MW. Pola relasi eksekutif dan legislatif pada penyusunan legislasi daerah. J Gov Public Pol. 2015;4(1):4173. https://doi.org/10.18196/jgpp.4173

7. Rismawan R. Implementasi kebijakan pembiayaan jaminan kesehatan pemerintah kota palu di era jaminan kesehatan nasional. J Kebijakan Kesehatan Indones. 2018;7(4):178-189. https://doi.org/10.22146/jkki.v6i3.29661

8. Rajan D, Barroy H, Stenberg K. Strategizing National Health in the $21^{\text {st }}$ Century: A Handbook. Geneva: World Health Organization; 2016.

9. Supriyantoro S. Formulasi kebijakan integrasi jaminan kesehatan daerah ke sistem jaminan kesehatan nasional menuju universal health coverage. J Kebijakan Kesehatan Indones. 2014;3(5):237. https://doi.org/10.24893/jkma.8.2.93-99.2014

10. Timumun FS. Analisis komparasi pembiayaan program jaminan kesehatan nasional dan program jaminan kesehatan daerah dalam pencapaian efektifitas anggaran pada dinas kesehatan kabupaten Buol. Katalogis. 2018;6(1):1-4. https://doi. org/10.25041/fiatjustisia.v10no4.808

11. Sahri M. Optimalisasi fungsi pengawasan DPRD terhadap pelaksanaan program jamkesda di kabupaten Bangkalan. J Hukum. 2014;1(1):1-5.

12. Syam A, Sari NP, Thaha AR, Suriah S, Jafar N, Salam A, et al. The effect of pumpkin seed flour (Cucurbita moschata Durch) on zinc serum levels in malnourished Wistar rats. Enferm Clin. 2020;30(4):337-40. https://doi.org/10.1016/j. enfcli.2019.10.095 